\title{
The Resilience of SMEs Facing Pandemic: A Case Study of Processed Seafood Products in Pekalongan City, Indonesia
}

\author{
Berta Bekti Retnawati ${ }^{1 *}$, Ch. Retnaningsih ${ }^{2}$ \\ ${ }^{1}$ Faculty of Economics and Business, Soegijapranata Catholic University, Indonesia \\ ${ }^{2}$ Faculty of Food Technology, Soegijapranata Catholic University, Indonesia \\ "Corresponding author. Email: berta@ unika.ac.id
}

\begin{abstract}
The difficult time caused by the Covid-19 pandemic outbreak proves that SMEs can survive even with serious problems that directly impact them. This research is a qualitative descriptive study by conducting interviews to 30 respondents of seafood-processing entrepreneurs in the city of Pekalongan. The interviews were conducted with business actors by using random sampling, and data collection was in form of convenience sample. Indepth interviews were conducted by exploring information on businesses carried out before the pandemic, during the pandemic, and adaptive efforts to survive in the new normal era. In the period before the pandemic, the amount of production per month of seafood-processing SME in Pekalongan Regency was quite diverse with the number of products varying from less than $100 \mathrm{~kg} / \mathrm{month}(7 \%)$ up to more than $1000 \mathrm{~kg} / \mathrm{month}(57 \%)$. Nevertheless, they have not used IT as a supporting means in their efforts. They continue to market their products directly in the area around Pekalongan and also outside Pekalongan area. During the Covid-19 pandemic, all SMEs' businesses continued but experienced significant declines such as difficult and expensive raw materials and a decrease in the number of buyers. On the other hand, the impact of pandemics on marketing and labour areas is not very significant. The marketing activities continue as before the pandemic and the employees work as usual. However, product innovation is minimal due to the lack of capital and knowledge. In the new normal era, all seafood-processing SMEs will continue their efforts. They will compete with the market, which remain optimistic that their products will improve so that they can increase the production. Besides, the new normal business plan for them is also like expanding the marketing and trying to be more successful. They also have specific targets to keep selling and continue to survive in the hope that the government can also synergize through the provision of assistance in form of the access to capital. This research concludes that the majority of SMEs in seafood-processing business are still able to survive in crises due to prolonged pandemics. Although they are able to stay and continue their efforts, there has not been innovation related to more adaptive marketing patterns, namely the utilization of digitalization.
\end{abstract}

Keywords: SMEs, Resilience, Pandemic

\section{INTRODUCTION}

The economic downturn caused by the Covid-19 pandemic has dealt a severe impact to micro, small, and medium-sized business. Recognizing the considerable number of SMEs in Indonesia which reached 64 million and the absorption of $97 \%$ of the workforce, the government continues to try to save the sustainability of their efforts. Policy stimulus are created to keep the wheels of the people's economy moving and avoid the weakness of people's business. The distribution of credit and assistance to SMEs to be able to adapt and survive in the pandemic situation is enterprising. Large government budget are allocated in order to help marketing the SMEs' products [1,2].
One of the sectors that absorbs a lot of raw material and labour is processed food, mainly processed sea-based food. Central Java is one of the provinces in Indonesia that has marine and fishery potential. Some areas in Central Java become centres for the number of fishermen and businesses engaged in this field such as Semarang, Demak Regency, Pekalongan, Rembang, Tegal, Brebes, and Cilacap. One of the areas that becomes a large barn of potential seafood is the city of Pekalongan. The north sea directly borders the city to the west of Central Java. Being on the coast makes Pekalongan have abundant fisheries and marine resources. The Nusantara Fisheries Port supports sea transportation for the berths of marine catches to be utilized by sea-based food processors. In addition to fishery products, there are also seaweed-processing businesses that are abundant enough to 
be marketed both in the local market and outside Pekalongan.

The situation of economic crisis due to the impact of this pandemic also positively impacts the seafood-processing SMEs. The government still relies on their ability to survive and remain resilient in this challenging situation. Nevertheless, the synergy among various parties is needed to maintain the sustainability of this seafood-processing business. This study seeks to look the at existing conditions both before and during the pandemics, as well as the efforts and expectations in times of new normality. The purpose of this research is to contribute a portrait of empirical conditions to provide input to policy makers to save the SMEs. They are the focus of hope to remain exist in the time of this crisis. This research was conducted to determine the efforts of SME resilience during a multi-dimensional crisis due to the Covid-19 pandemic.

\section{BACKGROUND}

\subsection{The Impact of Economic Crisis on Business}

The cause of crisis may come from various sources, namely natural disasters, technological disasters, and economic problems that can arise suddenly at any time with unimaginable impacts [3]. Crisis in nature is usually characterized by a low probability, ambiguity, high consequence decisions along with time pressure [4]. An economic crisis can affect companies in many different ways, and if not managed correctly, it will be costly for the organization [5].

Business pressures demand a reduction in production which resulted in a decrease in supply due to the reduction of market demand. A reduction in the number of workers is the next impact, or policy could emerge to pay sub-standard wages usually. This is an attempt to save corporate spending. Financial problems have also affected supply chains [6]. A supply disruption leads to decreased production and demand shortage which in turn causes unemployment [7]. Thus, a disorder in supply could damage not only the organization internally, but also externally since the reputation and trust with stakeholders are put to the test since it affects the brand equity $[8,9]$.

Supply disruptions could cause supply shocks in an industry. Supply shocks that initially only affect a single sector can spread quickly into other industries during a pandemic [10]. This means that the goods become less available. After that, the price of the products in specific industry increases, making consumption more high-priced and thus also less attractive. This time, it is different: it is a global pandemic, it is not solely affecting poor-income countries, but also the interest rates are down at significant level, and the whole world is going through the disruption of demand and supply [11].

\subsection{The Characteristics of SMEs in Times of Crisis}

Every time a crisis hits a country, small businesses become the economic backers for the people. Now in the pandemic era, it is proven that SME actors are enterprising and tenacious. In the community of creativity and innovation, they don't succumb to the plague. This is in line with another research mentioning that one of the success factors in facing the dynamics of the situation is that it has an entrepreneurial orientation with the speed of adapting to environmental changes that will provide opportunities for the SMEs' sustainability. Entrepreneurial actions capability is essential for businesses to develop new products, new processes, and new organizations through the modification and reconfiguration of resources, as well as addressing the pace of market change [12].

The Government's attention to SMEs is very tremendous; it is based on the collective awareness of all parties that SMEs are solving various economic crisis issues, including the consequences of this pandemic. The policy on SMEs is stated in Presidential Regulation No. 18/2020 on the National Medium-Term Development Plan for the period 2020-2024. In this regulation, among others, it is mentioned that the competitiveness of Micro, Small, and Medium Enterprises (SMEs) needs to be continuously improved through policies that encourage SMEs to be more productive and contribute more considering the amount of labour absorption reaches about 97 percent. The increase in capacity and added value of SMEs was carried out through the ease of effort, expansion of market access, accelerated financing, increased human resource capacity, and strengthened cross-sector coordination [13].

The efforts to build and empower the community through the assistance of SMEs today receive considerable attention from various parties, both government, banking, private, non-governmental organizations, and international institutions. During this pandemic, the contribution of SMEs receives more attention, because the most considerable economic activities are run by SMEs. The assistance of SMEs to optimize the utilization of resources both from inside and outside the business such as mentoring in entrepreneurship, business management, financial management, production, and technology-based marketing for SME actors to be provided with technical aspects in making business planning that will be implemented by SMEs [15]. 


\section{METHOD}

This research is a qualitative descriptive study by conducting interviews to 30 respondents of seafoodprocessing entrepreneurs in the city of Pekalongan. Interviews were conducted with business actors by random sampling, and data collection was in form of convenience sample. In-depth interviews were conducted by exploring the information on businesses carried out before and during the pandemic, as well as the adaptive efforts to survive in the new normal era.

\section{ANALYSIS AND DISCUSSION}

\subsection{Respondent Profile}

The following profiles of respondents in seafoodprocessing business in Pekalongan City are as follows:

Table 1 Respondents' Profile

\begin{tabular}{|c|c|c|c|c|}
\hline No & Classification & $\begin{array}{c}\text { Sub- } \\
\text { Classification }\end{array}$ & Total & $\begin{array}{c}\text { Percentage } \\
(\%)\end{array}$ \\
\hline \multirow[t]{2}{*}{1} & Gender & Male & 20 & 67 \\
\hline & & Female & 10 & 33 \\
\hline \multirow[t]{7}{*}{2.} & Type of Product & Salted Fish & 19 & 51 \\
\hline & & Pindang Fish & 8 & 22 \\
\hline & & Ebi & 1 & 3 \\
\hline & & Fresh Fish & 3 & 8 \\
\hline & & Grilled Fish & 3 & 8 \\
\hline & & Tuna Fish & 2 & 5 \\
\hline & & Banyar Fish & 1 & 3 \\
\hline \multirow[t]{2}{*}{3.} & Cluster & Yes & 0 & 0 \\
\hline & & No & 30 & 100 \\
\hline \multirow[t]{3}{*}{4.} & Business Age & 1-5 year & 5 & 17 \\
\hline & & $6-10$ year & 7 & 23 \\
\hline & & $>10$ year & 18 & 60 \\
\hline \multirow[t]{5}{*}{5.} & Education & $\begin{array}{l}\text { Elementary } \\
\text { School }\end{array}$ & 7 & 23 \\
\hline & & Junior High & 9 & 30 \\
\hline & & High School & 11 & 37 \\
\hline & & D1 & 1 & 3 \\
\hline & & D3 / Bachelor & 2 & 7 \\
\hline \multirow[t]{4}{*}{6.} & Employees & Self-employees & 1 & 3 \\
\hline & & 1-5 employees & 16 & 53 \\
\hline & & 6-10 Employees & 7 & 23 \\
\hline & & >11 Employees & 6 & 20 \\
\hline
\end{tabular}

Source: Processed Primary Data (2020)

Table 1 describes that 30 respondents of seafood-processing business in Pekalongan Regency, dominated by men with the final education high school / vocational school. Based on the survey results, there are seven types of seafood products produced by the SMEs such as salted fish, pindang fish, Ebi, fresh fish, grilled fish, tuna fish, and banyar fish. Salted fish is one of the most processed types of seafood products made by SMEs. In running their business, SMEs have a diverse number of employees. But there are also SMEs that have no employees. Besides, judging by the lifespan of the company, with a minimum business life of 1 year even some that are more than ten years old, all SMEs have not been included in the cluster.

\subsection{Pre-Pandemic Condition}

Table 2 Production/Month Before Pandemic

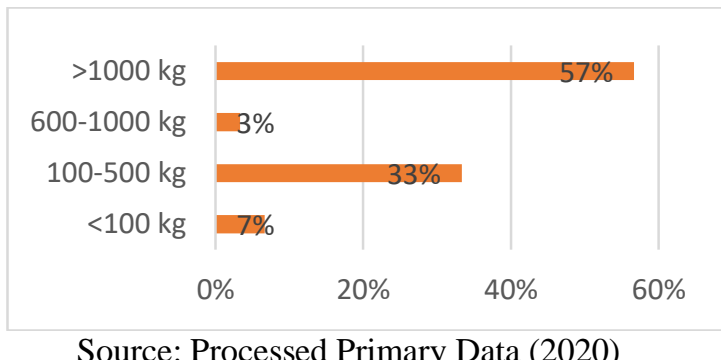

Based on the production/month chart, there are 57\% SMEs that produce more than $1000 \mathrm{~kg} /$ month of processed food. There are also SMEs producing 100-500 kg/month (33\%) and $600-1000 \mathrm{~kg} / \mathrm{month}(3 \%)$ of processed food. On the other hand, there are also SMEs $(7 \%)$ with production per month of less than $100 \mathrm{~kg}$.

Table 3 Pre-Pandemic Marketing Area

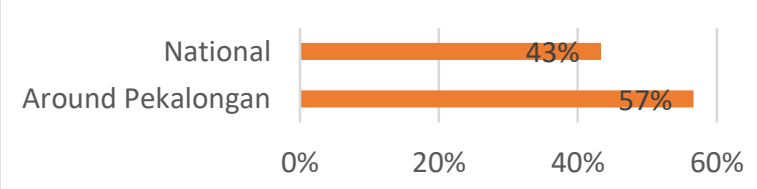

Source: Processed Primary Data (2020)

A total of $57 \%$ of seafood-refinary SMEs market their products around Pekalongan, and as many as $43 \%$ of the SMEs market their products outside Pekalongan (National).

Table 4 The Use of IT Before Pandemic

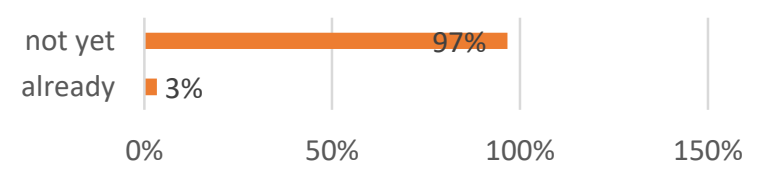

Source: Processed Primary Data (2020)

As many as $97 \%$ of the SMEs have not utilized IT in running their business. However, there are $3 \%$ of the SMEs who have already used IT (Instagram promotion) for marketing their products. 


\subsection{Pandemic Conditions}

During the pandemic, the business situation in Pekalongan Regency continues to run $(100 \%)$ as usual. Based on the results of the survey among 30 respondents, no SMEs were found to have temporarily suspended their business during the pandemic. Nevertheless, the impact on sales during the pandemicera, all (100\%) SMEs have got a declining effect on their business. The results of the survey through the diagram show that there are no SMEs $(0 \%)$ that have no impact on their business. Specifically, the situation that occurs in the sales is as follows.

Table 5 Specific Situations in Sales

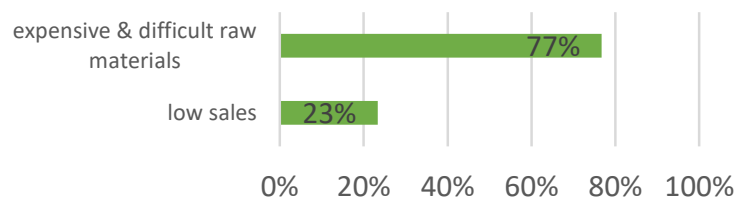

Source: Processed Primary Data (2020)

Based on the diagram above, as many as $30 \mathrm{SME}$ respondents experienced a decline in sales. The specific effects of the decline are the difficulty to obtain and the cost of raw materials as well as low-volume sales. As many as $77 \%$ of SMEs experience the difficulty in obtaining raw materials, and the price of raw materials has become more expensive. Then, as many as $23 \%$ of SMEs experienced low-volume sales.

As for how many SMEs are adapting, it appears that the number is minimal. During the pandemic period in terms of adaptation, as many as $40 \%$ of SMEs continue to run their businesses. Then, as many as $60 \%$ of SMEs do not adapt in their efforts during the pandemic period.

Table 6 The Number of SMEs Adapting

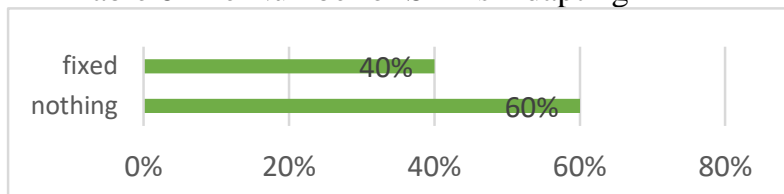

Source: Processed Primary Data (2020)

Moreover, in looking at product innovation data, almost all SMEs remain on their initial products before the pandemic, considering that in times of crisis they continue to run business as usual and can still survive despite the decrease in the number of sales (turnover).

Table 7 Product Innovation

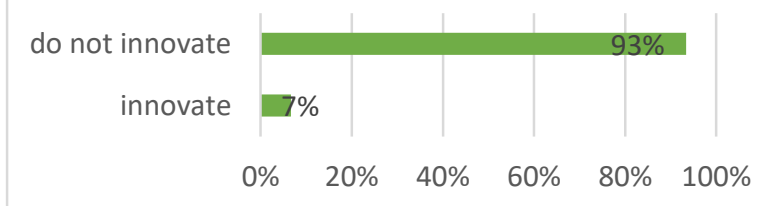

Source: Processed Primary Data (2020)
From the diagram above, it is known that $93 \%$ of SMEs do not innovate their processed products. This is due to capital limitations. Also, as many as $7 \%$ of SMEs innovate the products they sell, such as selling fresh fish.

Meanwhile, the impact on marketing is as follow:

Table 8 The Effect of Marketing Area during Pandemic

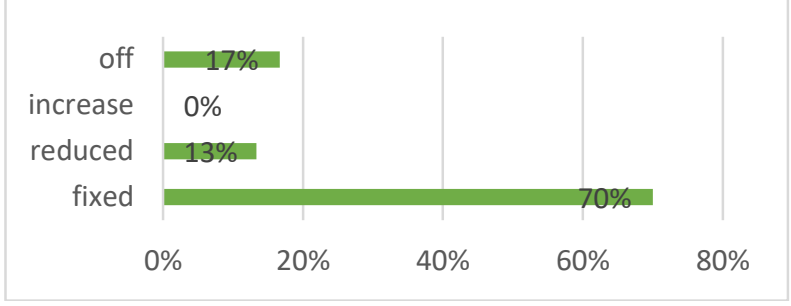

Source: Processed Primary Data (2020)

In the diagram about the impact of the pandemic on marketing area, it is known that $70 \%$ of SMEs still conduct their sales in the same marketing area as they did before the pandemic. However, as much as $13 \%$ of SMEs have their marketing area reduced. This can occur because the marketing area is outside the affected area of Pekalongan by Covid-19. As much as $17 \%$ of SMEs stop marketing their products during the pandemic due to no production.

During the pandemic, most SMEs do not do the lay-offs. As many as $93 \%$ of SMEs continue to employ the same employees as they did before the pandemic. A total of $7 \%$ of SMEs reduce the number of employees during the pandemic.

\subsection{Hope in the New Normal}

When asking the SMEs about business sustainability in the new normal, the plan of all food-processing SMEs is to continue their business. The SMEs will compete with the market, remain optimistic that the production will recover and increase. Also, the new normal business plan for the SMEs is like expanding the marketing and trying to be more successful.

In the new normal, as many as $97 \%$ of SMEs do not innovate their products. However, they want to innovate their business, expand the marketing, maintain the product quality, and prepare the next generation in fish processing business. On the other hand, there are still 3\% of SMEs that innovate in the new normal. The innovation can be in form of improving the packing from wooden blocks to cardboard.

The specific targets that the SMEs want to do are as follows: 
Table 9 New Normality’s Specific Targets

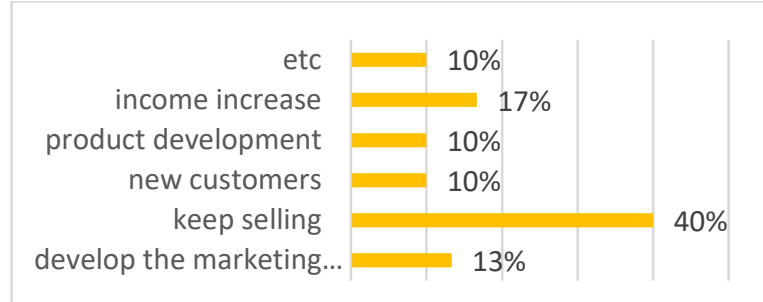

$\begin{array}{llllll}0 \% & 10 \% & 20 \% & 30 \% & 40 \% & 50 \%\end{array}$

Source: Processed Primary Data (2020)

In the chart above, it is known that $40 \%$ SMEs during the new normal period keep selling and continue to survive. As much as $17 \%$ of SMEs and $13 \%$ of SMEs have the targets to increase revenue and expand their marketing, while 10\% of them have the target to find new customers, add new products, and achieve other specific targets. Other specific targets include having freezer tools, always praying and trying, and answering questions from consumers.

The expectations that SMEs want to do in the new normal are as follows:

Table 10 Hope in the New Normal

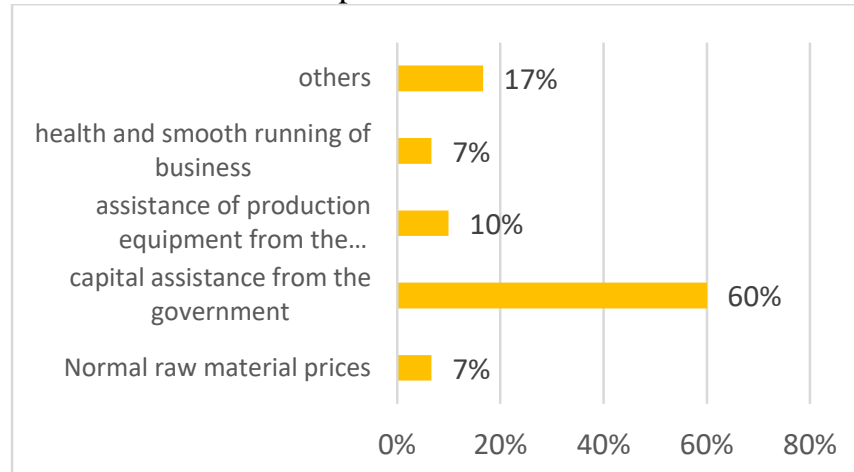

Source: Processed Primary Data (2020)

The desired expectation (60\%) among the SMEs during the new normal is to acquire the supply of funds / capital from the government. As much as 10\% of SMEs expect the tool assistance from the government. The tools support is expected to be in form of a large box and freezer. As much as $7 \%$ of SMEs each expect to be healthy and run business smoothly, and hope that the price of raw materials remains normal. Meanwhile, $17 \%$ of SMEs have other expectations such as do not always depend on the government, the government policy can be flexible according to the circumstances, the government can visit their locations, the decrease in electric power rate, and can be better in addressing the pandemic situation.

\section{CONCLUSION}

In the period before the pandemic, the amount of production per month by seafood-processing SMEs in Pekalongan Regency was quite diverse with the amount less than 100 $\mathrm{kg} / \mathrm{month}$ (7\%), 100-500 kg/month (33\%), 600-1000 $\mathrm{kg} / \mathrm{month}(3 \%)$, and more than $1000 \mathrm{~kg} /$ month (57\%). Although there are $57 \%$ of SMEs whose total production per month is more than $1000 \mathrm{~kg}$, they (97\%) do not yet utilize the IT as a supporting mean in their efforts. This is not considered an obstacle, because the SMEs continue to market their products directly in the environment around Pekalongan and also outside Pekalongan area.

During the Covid-19 pandemic, all SMEs' businesses continue but experience significant declines such as the difficult and expensive raw materials as well as a decrease in the number of buyers. Besides, the impact of pandemic on marketing and labour-areas is not very significant. Marketing is still done as it was before pandemic and employees still work as usual. Although there are also SMEs that have experienced reduced employees and marketing, SMEs continue to sell. During the pandemic period, most SMEs do not innovate their products due to the lack of capital.

In the new normal period, it can be concluded that $100 \%$ of seafood-processing SMEs will continue their efforts. They will compete with the market, remain optimistic that production will recover and increase. Also, the new normal business plan from them is also like expanding the marketing and trying to be more successful. In the new normal, $97 \%$ of SMEs do not explicitly innovate their products, but persist and move towards developing their business, expanding their marketing, maintaining their product quality, and preparing their next generation in fish processing business. In the new normal, companies also have unique targets to keep selling and continue to survive in the hope that the government can also synergize through the provision of assistance in the form of funds.

This research concludes that the majority of SMEs in seafood-processing business are still able to survive in crisis due to prolonged pandemics. Although they are able to stay exist and continue their efforts, there has not been innovation related to more adaptive marketing patterns, namely the utilization of digitalization. Currently, their technology literacy for marketing is still low. This needs to be followed up by providing the mentoring for seafoodprocessing SMEs in order to become more technologically literate. The mentoring activities should be done continuously and carefully considering that they are very familiar with the habit of simply producing and marketing. A change in mindset to be more adaptive is also indispensable. 


\section{ACKNOWLEDGMENT}

The Authors would like to thank the research funding assistance through the National Competitive Basic Research grant from the Indonesia Ministry of Research, Technology, and National Research and Innovation Agency for the 2020 Fiscal Year.

\section{REFERENCES}

[1] Lili Marlinah, Peluang dan Tantangan UMKM Dalam Upaya Memperkuat Perekonomian Nasional Tahun 2020 Ditengah Pandemi Covid 19, Jurnal Ekonomi, Volume 22 Nomor 2, Juni 2020 p 118-124

[2] Bhwana, Petir Garda, Ministry Proposes Soft Loans for SMEs Affected by COVID19. Tempo.co. accessed 22 April 2020. https://en.tempo.co/read/1327970/minist ry-proposes-soft-loans-for-smesaffected-by-covid-19.

[3] R.Grewal, \& Tansuhaj, P. Building organizational capabilities for managing economic crisis: The role of market orientation and strategic flexibility. Journal of Marketing. 2001. Vol.65, pp. 67-80. https://doi.org/10.1509/jmkg.65.2.67.18259

[4] C.M. Pearson \& Clair, J. A. Reframing Crisis Management. Academy of Management Review, 1998. 23(1), 59-76. https://doi.org/105465/amr.1998.192960

[5] A. Ghandour, \& Benwell, G. A framework of business recovery in the aftermath of a disaster. International Journal of Business Continuity and Risk Management, 2012. 3(3), 263-274. https://doi.org/10.1504/IJBCRM.2012.050490

[6] A. Ghandour, \& Benwell, G. A framework of business recovery in the aftermath of a disaster. International Journal of Business Continuity and Risk Management, 2012. 3(3), 263-274. https://doi.org/10.1504/IJBCRM.2012.050490

[7] V. Guerrieri, Lorenzoni, G., Straub, L., \& Werning, I. (2020). Macroeconomic implications of COVID-19: Can negative supply shocks cause demand shortages? 2020. National Bureau of Economic Research. https://doi.org/10.2139/ssrn.3570096

[8] A. Ghandour, \& Benwell, G. A framework of business recovery in the aftermath of a disaster. International Journal of Business Continuity and Risk Management, 2012. 3(3), 263-274.

https://doi.org/10.1504/IJBCRM.2012.050490
[9] L. He, \& Ran, Y. The correlation of brand equity and crisis: A review and directions for future research. Modern Economy. 2015, 6(03), 392-397.

https://doi.org/10.4236/me.2015.63036

[10] V. Guerrieri, Lorenzoni, G., Straub, L., \& Werning, I. (2020). Macroeconomic implications of COVID-19: Can negative supply shocks cause demand shortages? 2020. National Bureau of Economic Research. https://doi.org/10.2139/ssrn.3570096

[11] N. Fernandes, Economic effects of coronavirus outbreak (COVID-19) on the world economy. 2020. Available at SSR: https://ssrn.com/abstract=3557504

[12] F.M. Cesaroni, Sentuti, A., \& Cubico, S. Small family firms and strategies coping the economic crisis: The influence of socio-emotional wealth. 2020. In Entrepreneurship and Family Business Vitality (pp. 2748). Springer, Cham. https://doi.org/10.1007/978-3030-15526-1_3

[13] Wan Laura Hardilawati, Strategi Bertahan UMKM di Tengah Pandemi Covid-19 The Survival Strategy Of SMEs During The Covid-19 Pandemic. 2020, Jurnal Akuntansi \& Ekonomika, Vol. 10 No. 1, Juni

[14] Adriani Kala'lembang, Adopsi E-Commerce Dalam Mendukung Perkembangan Usaha Mikro Kecil Dan Menengah (UMKM) Di Masa Pandemi Covid-19 2020, Capital Jurnal Ekonomi dan Manajemen

[15] Syamsul Hadi \& Supardi, Revitalization Strategy for Small and Medium Enterprises after Corona Virus Disease Pandemic (Covid-19) in Yogyakarta, 2020, Journal of Xi'an University of Architecture \& Technology, Vol XII, Issue IV. 